日植病報 $32: 181 \sim 185$ (1966).

Ann. Phytopath. Soc. Japan $32: 181 \sim 185$ (1966).

\title{
Double infection by an incompatible race of Phytophthora infestans of a potato plant cell which has previously been infected by a compatible race.*
}

\author{
Kohei TomiYAma** \\ 冨山宏平**: あらかじめ親和性疫病菌レースの感染を受けたジャガイモ \\ 細胞に対する非親和性レースの二重感染
}

\begin{abstract}
A potato plant cell can survive for longer than two days after the infection by a compatible race of Phytophthora infestans. On the contrary, it dies hypersensitively within about 30 minutes after infection by an incompatible race in this experimental condition.

When a potato plant cell, which has been infected by a compatible race of Phytophthora infestans 15-20 hours previously, was reinoculated with an incompatible race, no celldeath caused by the hypersensitive reaction to the latter occurred at least within four hours. However, several hours after the primary infection by the compatible race, occurrence of the hypersensitive death of the host cell caused by the secondary infection by the incompatible race was only slightly delayed. The control cell treated in the same way, except the previous infection by the compatible race, died within ten to twenty minutes after the infection by the incompatible race. It is concluded, therefore, that the potato plant cells gradually lose their hypersensitivity to the incompatible race after the infection by the compatible race.
\end{abstract}

(Received December 6, 1965)

\section{Introduction}

There is a marked difference between compatibility and incompatibility in host-parasite relationships of potato late blight ${ }^{1,10)}$. When a potato plant cell is infected by an incompatible race of Phytophthora infestans, the former dies hypersensitively within about 30 minutes when the former is metabolically active $e^{4,5,7,8,9)}$. With a compatible race, on the contrary, the infected host cell survives far longer in peaceful coexistence with the parasite, possibly for 2-3 days. It is generally accepted that this hypersensitivity is controlled by independent Mendelian type genes. To know why a host cell reacts differently to different races is one of the most important problems in the field of host-parasite physiology, but no satisfactory explanation has been given. This constitutes a wider problem, "the specificity in the host-parasite relationship".

There may be many different ways to approach this problem, but in this report the author raises a question, whether:

1) Some unknown principles of a pathogene specifically cause the hypersensitive death of an incompatible host-cell.

* Cell physiological studies on resistance of potato plants to Phytophthora infestans. $\mathrm{X}$.

** Hokkaido Agriculture Experiment Station, Sapporo, Japan. 北海道農業試験場 
2) Or in the compatible host-parasite combination, some unknown system can specifically retard the occurrence of the hypersensitive cell-death which may otherwise take place in any contact between the host and the parasite.

In the experiments reported here, it was planned to learn how a potato-plant cell which has previously been infected by a compatible race responds to the secondary infection by an incompatible race of Phytophthora infestans.

\section{Materials and Methods}

The potato variety Kennebec having $R_{1}$-gene, which is highly resistant to race 0 and susceptible to race 1 , was used throughout these experiments. A potato-leaf petiole was cut longitudinally with a razor and washed with streaming water for a short period to eliminate the contents of the destroyed cells. After being washed, the cut surfaces of half of the petioles were inoculated with the compatible race (race 1) of $P$. infestans, and the other half were left uninfected. Both halves, infected and uninfected, were kept in a large Petri dish at $19^{\circ} \mathrm{C}$ under dark condition for 15-20 hours. Then they were taken from the incubator and reinoculated with race 0 , the incompatible race. In another experiment, the cut petioles were kept in an incubator at $19^{\circ} \mathrm{C}$ for 15-20 hours before inoculating half of them with race 1 . Five to six hours after inoculating with race 1 , both halves, the infected and uninfected, were secondarily inoculated with race 0.

The zoosporangia suspension of Phytophthora infestans obtained from the mycelium mat grown on the cut surface of fresh potato-tubers was allowed to germinate at $11-12^{\circ} \mathrm{C}$. After removal of ungerminated zoosporangia by centrifugation, the supernatant zoospore-suspension was used for inoculation. Just before the second inoculation with race 0 , the cut surface previously infected by race 1 was thoroughly washed with running water to eliminate the zoospores which have not yet attached to the cell surface.

After the secondary inoculation with race 0 , periodically microscopic sectios were made from the infected cut surface and examined under a microscope. The cells which had been infected by one or two infecting hyphae of race 1 and then secondarily infected by one or two of race 0 were chosen. Observations were made on these selected cells.

Death of the infected cells was determined microscopically by using vital staining with neutral red and protoplasmic streaming as criteria. Granulation of cytoplasm also could serve as criteria. The time required for death of host cell was deduced from the graph by plotting the percentages of dead cells per total infected cells as ordinates and time as abscissas.

To determine the time required for the penetration by the parasite, microscopic observations of the penetration of cells by appressoria were made at certain intervals after inoculation. The time was deduced from the graph by plotting the percentages of penetrated cells per total cells attached by appressoria as ordinates and time as abscissas.

\section{Results}

Both races used in the present experiments, race 0 and race 1 , are almost the same in their morphological appearance. Moreover, they can penetrate into the host cells at almost the same velocity in both cases of compatibility and incompatibility. The further growth of the mycelium of both races in the compatible and incompatible host cells is almost the same in an initial period of infection ${ }^{3,7,8)}$. It is, therefore, impossible to distinguish between the intracellular hyphae of both races, if they were inoculated at the same time. Since most of the zoospores can finish 

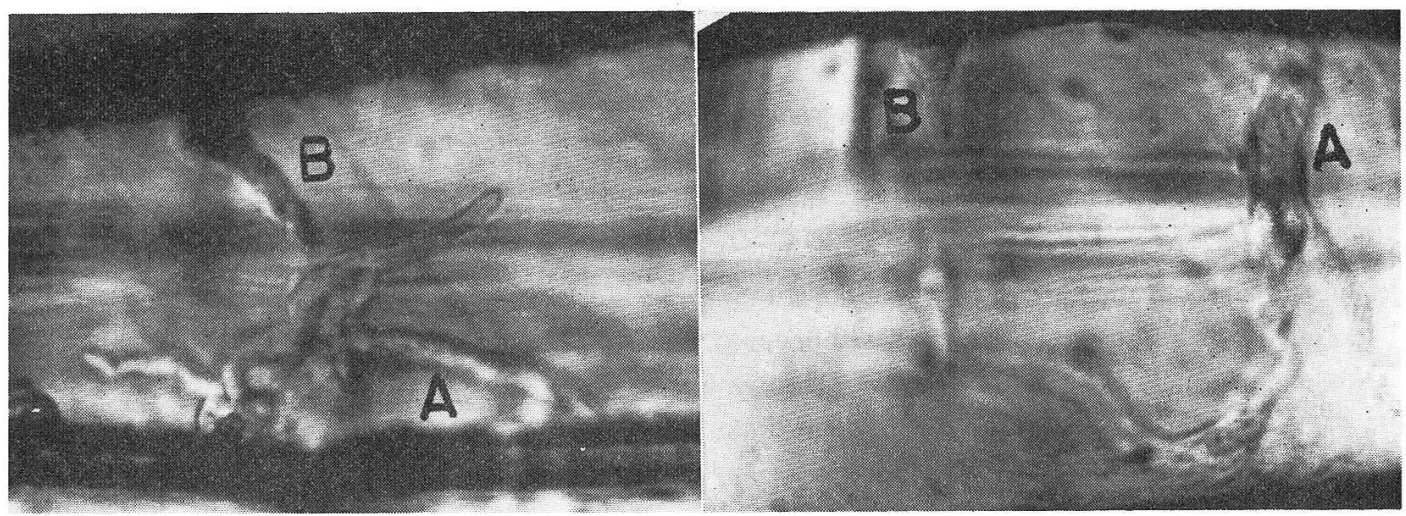

Fig. 1. The cells infected by both race 0 and race 1 .

$A$ : race 1 . $B$ : race 0 .
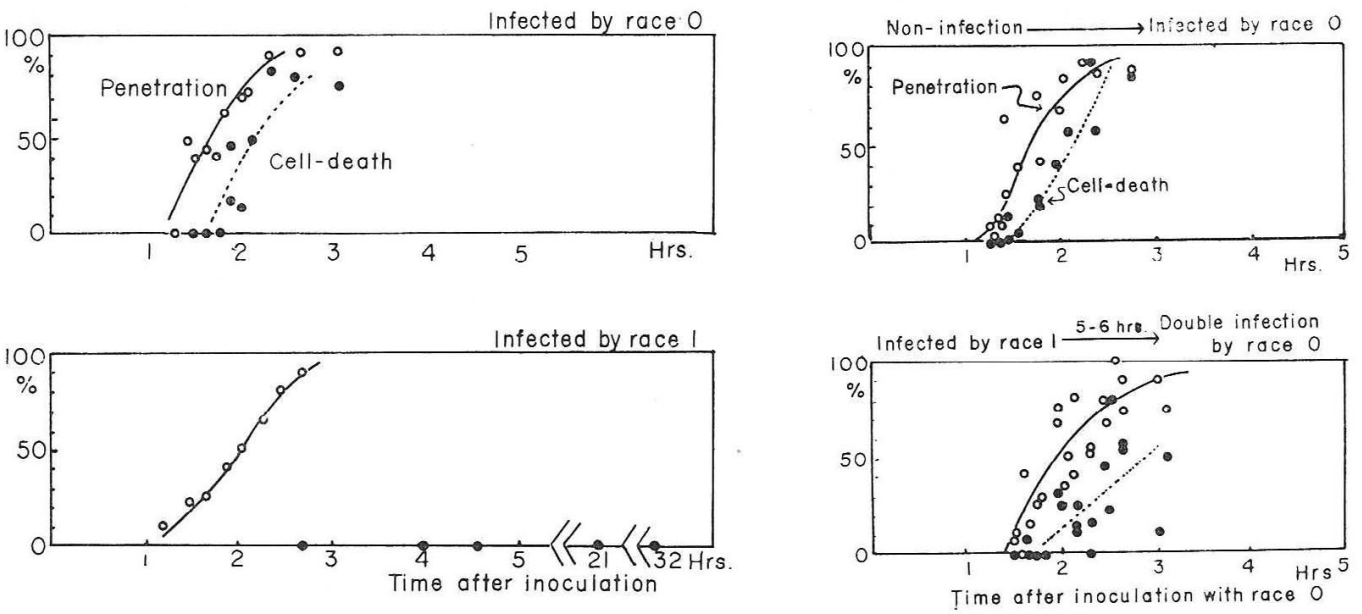

Fig. 2. Death of the potato plant cells infected by the incompatible race (race 0 ) and the compatible race (race 1 ). Ordinate: Percentages of penetrated cells per total cells attached by appressoria and also percentages of the dead cells per total cells infected. Cut surfaces of the petioles of potato plants were exposed to air for about 15 hours before

Fig. 3. The time required for the hypersensitive death of the potato plant cells which have previously been infected by the compatible race (race 1) and were reinfected by the incom. patible race (race 0) 5-6 hours after the primary infection. inoculation.

their penetration during a short term and grow further, the firstly infecting hyphae can be discerned from the secondarily infecting hyphae, provided the latter is inoculated several hours after inoculation with the former (Fig. 1).

When the cells in the cut surface tissue of petioles are infected by the compatible race, the host cells which are invaded keep alive more than two days (Fig. 2). Therefore, if the host cells involving race 1 were killed after the secondary infection by the incompatible race, it can be concluded that the cell-death was caused by the hypersensitive reaction of the host cell to the latter. When the cut-surface cells, which have been infected with the compatible race, 5-6 
hours previously, were secondarily inoulated with the incompatible race, occurrence of the hypersensitive cell-death caused by the secondary infection was a little delayed (Fig. 3). However, when the double infection by the incompatible race was made $15 \sim 20$ hours after the primary infection by the compatible race, no death of the host cells occurred within approximately four hours after the penetration (Fig. 4). The microscopic observation was stopped about four hours after the penetration because the hyphal growth of the secondarily inoculated parasite made it difficult to distinguish between the firstly and secondarily infecting hyphae. When the control cells were treated in the same way, except the previous infection by race 1 , the invaded host cells were killed hypersensitively within ten minutes after the infection by the incompatible race.
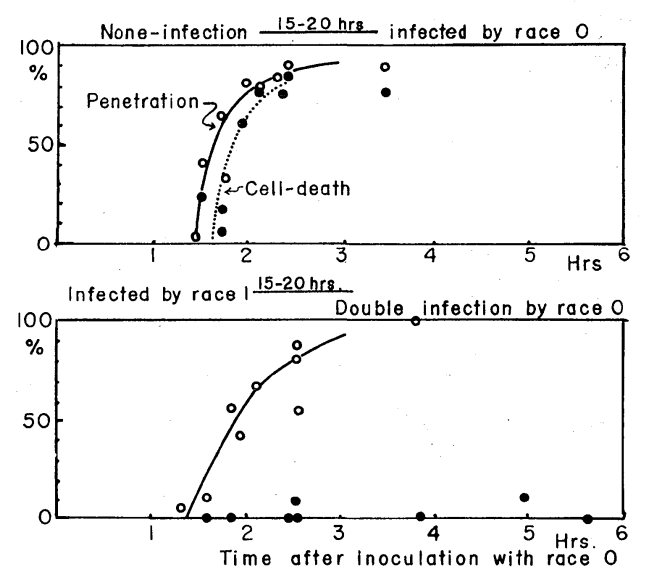

Fig. 4. The time required for the hypersensitive death of the potato plant cells, which had previously been infected by the compatible race (race 1 ) and were reinfected by the incompatible race (race 0) 15-20 hours after the primary infection.

\section{Discussion}

The above described results clearly indicate that the cells which have been infected by the compatible race of $P$. infestans 15-20 hours previously still are alive, but have already lost their hypersensitivity to the incompatible race. Several hours after the infection by the compatible race, however, the delay in occurrence of the hypersensitive cell-death was only slight.

In previous papers ${ }^{5,7,8,9)}$, the author indicated that when metabolic activity of the host cell is reduced, the hypersensitive death caused by infection by the incompatible race is very much delayed. It seems, therefore, to the author, that metabolic activity of the host cell may be retarded by the contact with the compatible parasite and thus gradually lose its ability to react rapidly to infection by the incompatible race. It was shown in a former paper ${ }^{2)}$ that the ratio of water soluble protein $-\mathrm{N}$ to total- $\mathrm{N}$ and the phenols contents are decreased in the potato tuber tissue when infected by the compatible race. This seems to suggest the reduction of metabolic activity by infection by the compatible race.

About 2 days after infection, the nucleus was deformed in the cells infected by the compatible race of $P$. infestans. The protoplasmic streaming was slowed down. These phenomena also suggest that the physiological state of the cells is severely altered by the infection of the compatible race.

Further work is required to answer the question raised in the head of this report.

The phenomenon reported here indicates that the cells infected by the compatible race gradually lose their ability to react hypersensitively. This seems to suggest that failure in rapid hypersensitive reaction to the parasite in an initial period of infection may accelerate the delay in occurrence of hypersensitive cell-death. Little difference in an initial period of infection may be possible to cause a great difference in disease resistance. 


\section{Literature cited}

1. Müller, K.O. (1959). Hypersensitivity. Plant pathology I: 469-519. Academic press, New York.

2. Tomiyama, K., N. Takase, R. Sakai and M. Takakuwa (1956). Ann. Phytopath. Soc. Jap. 20: 59-64.

3. Tomiyama, K., M. Takakuwa, N. Takase and R. Sakai (1959). Phytopath. Z. 37: 113-144.

4. Tomiyama, K. (1956). Ann. Phytopath. Soc. Jap. 20: 165-169.

5. Tomiyama, K. (1957). Ann. Phytopath. Soc. Jap. 22: 75-78.

6. Tomiyama, K. (1957). Ann. Phytopath. Soc. Jap. 28: 129-133.

7. Tomiyama, K. (1957). Ann. Phytopath. Soc. Jap. 22: 237-242.

8. Tomiyama, K. (1960). Phytopath. Z. 39: 134-148.

9. Tomiyama, K. (1966). Phytopath. Z. (in press).

10. Tomiyama, K. (1963). Ann. Rev. Phytopathology 1: 295-324.

\section{和交摘要}

あらかじめ親和性疫病菌レースの感染を受けたジャガイモ 細胞に対する非親和性レースの二重感染

$$
\text { 冨山宏平 }
$$

無感染健全ジャガイモ( $R_{1}$-遺云子) 細胞に非親和性レースが侵入すると短時間（約 $10 \sim 20$ 分間）のらち に宿主細胞は死にいたる。親和性レースでは感染後 $2 \sim 3$ 日間宿主細胞は死なずに共生関係が成立する。親 和性レースの感染後 5 6 時間で不親和性レースを同一細胞に接種すると, 宿主の過敏感死は若干拈くれる にすぎないが，15〜20 時間後に接種すると，過敏感死は非親和性レース侵入後少くも 4 時間以内では起ら ない（4 時間以上の観察は誤りを生ずる恐れがあつて行わなかつた)。

以上から $\mathrm{R}_{1}$-遺伝子による細胞の過敏感性は親和性レース侵入によつて徐々に失われ，15〜20 時間後に はいちじるしく失われていると結論する。 